Огляди літератури, оригінальні дослідження, погляд на проблему, випадок з практики, короткі повідомлення удК 616.831-005.4-036.1:611.81

DOI 10.11603/1811-2471.2020.v.i4.11764

\title{
МОРФОМЕТРИЧНА ХАРАКТЕРИСТИКА ГОЛОВНОГО МОЗКУ У ХВОРИХ НА ХРОНІЧНУ ІШЕМІЮ МОЗКУ
}

\section{Тернопільський найональний медичний університет імені я. Горбачевського МОз. У. Насалик \\ Тернопільський національний медичний університет імені І. Я. Горбачевського мОз України}

РЕЗЮМЕ. Вивчення структурних змін головного мозку у пацієнтів з хронічною ішемією мозку (XIM), з'ясування їх зв' язку з когнітивними розладами сприяє удосконаленню діагностичних підходів та оптимізації прогнозування перебігу захворювання.

Мета - оцінити стан головного мозку за допомогою визначення морфометричних показників у хворих на XIM з наявністю гідроцефалії (ГЦ) та дослідити їх взаємозв' язок з когнітивною сферою.

Матеріал і методи. Проведено комплексне обстеження 140 пацієнтів з ХІМ та ГЦ. Враховували локалізацію ГЦ, дані Монреальського когнітивного тесту. Оцінювали дані комп'ютерної томографії головного мозку з подальшим визначенням морфометричних показників та індексів. Для статистичної обробки результатів користувались програмами Microsoft Excel 2011, Statistica.

Результати. За даними морфометрії, у пацієнтів з хронічною ішемією мозку виявляли як внутрішню форму ГЦ (у 50 хворих (35,71\%)), так і зовнішню (у 30 хворих $(21,43 \%))$ та змішану ГЦ (у 60 хворих (42,86 \%)). Середній бал за шкалою МОСА у хворих на XIM з ГЦ склав $(15,65 \pm 4,11)$, у хворих на XIM без ГЦ - $(20,64 \pm 2,59)$. Встановлено помірний зворотний кореляційний зв'язок ( $r=-0,39, p=0,010)$ між значенням за шкалою МоСА та розміром лівого бокового шлуночка, МоCA/IX ( $r=-0,32, p=0,016)$, МоСА/ІЦЧБШ $(r=-0,31, p=0,043)$, МоСА/БФІ $(r=-0,36, p=0,011)$, MoCA/ індексом Шлатенбрандта - Нюрнберга $(r=-0,44, p=0,012)$, МоСА/ІФР $(r=-0,32, p=0,002)$, МоСА/3 шлуночок ( $r=-0,35$, $\mathrm{p}=0,012) ;$ МоСА /САП (полюс лобної частки) ( $r=-0,30, p=0,012)$. У групах пацієнтів із внутрішньою та змішаною ГЦ виявлено вірогідно гірші морфометрчні характеристики. Встановлена залежність між морфометричними показниками, які свідчать про підкіркову та кіркову церебральну атрофію, та вираженням когнітивного дефіциту залежно від форми ГЦ.

Висновки. У пацієнтів з хронічною ішемією мозку змішану ГЦ було виявлено у 4286 \%, внутрішню - у 35,71 \%, зовнішню -у 21,43 \% обстежених. Виявлена залежність між морфометричними показниками, які свідчать про підкіркову та кіркову церебральну атрофію, та вираженням когнітивного дефіциту.

КлючовІ СловА: хронічна ішемія мозку; гідроцефалія; комп'ютерна томографія; церебральна атрофія.

Вступ. Згідно з сучасними уявленнями, хронічну ішемію мозку (ХIM) розглядають як синдром хронічного прогресуючого багатовогнищевого або дифузного ураження головного мозку різної етіології, який проявляється різноманітними неврологічними, нейропсихологічними і психічними порушеннями, що розвиваються внаслідок повторних гострих порушень мозкового кровообігу та/ або хронічної недостатності кровопостачання головного мозку.

Когнітивні й емоційні порушення $\epsilon$ закономірною складовою частиною клінічної картини XIM. Актуальним залишається питання прогресування судинної деменції у хворих на XIM $[1,2]$. Достеменно не відомо, що провокує поширеність цього ускладнення $[3,4]$. Результати досліджень інколи $\epsilon$ досить суперечливими, достовірний взаємозв' язок між рівнем АТ, біохімічними показниками, віком хворих, фоновим захворюванням не завжди чітко прослідковується.

Як свідчать дані сучасної літератури, було проведено чимало досліджень з метою виявлення взаємозв' язку між морфометричними показниками головного мозку та ступенем вираження когнітивних функцій, результати яких $\epsilon$ поодинокими, а інколи й суперечливими [5]. Зокрема, у досліджен- ні Teipel S. J. та співавт. [6] та Scher A. І. і співавт. [7] був виявлений взаємозв'язок між об'ємом гіпокампа та станом когнітивних функцій. Maоyu Li та співавт. [8] довели, що у пацієнтів з помірними когнітивними розладами та з хворобою Альцгеймера церебральна гіпотрофія корелює з когнітивним дефіцитом, у дослідженні Lu H. та співавт. [9] був вивлений взаємозв' язок між гіпотрофією кори головного мозку в залежності від ділянки та когнітивними розладами.

Атрофія мозку спостерігається майже при всіх типах деменції. Це викликано втратою об' єму головного мозку [10]. Дослідження з використанням лінійних та об' ємних методів МРТ для дослідження атрофії головного мозку були запропоновані для відстеження ступеня цього зниження [11].

Своєчасне виявлення та динамічне визначення ступеня вираження атрофії та об'єму вогнищевого пошкодження має важливе значення для діагностики, моніторингу та призначеня ефективної терапії пацієнтам із неврологічними захворюваннями [12].

Біфронтальний індекс (BFI) і співвідношення шлуночків мозку, як непрямі показники субкортикальної атрофії, були використані багатьма дослідниками для дослідження структурних уражень го- 
Огляди літератури, оригінальні дослідження, погляд на проблему, випадок з практики, короткі повідомлення ловного мозку у пацієнтів з деменцією. Як об'ємні, так і лінійні вимірювання $є$ надійнішими, ніж ті, які були зроблені посмертно, оскільки шлуночки мають тенденцію скорочуватися після смерті [13]. Однією з найбільш ранніх змін, що спостерігаються при атрофії головного мозку, є дилатація лобних рогів бічного шлуночка. Встановлено, що BFI $\epsilon$ одним з найбільш послідовних і практичних лінійних вимірювань, порівняно з іншими показниками, для оцінки ранньої мозкової атрофії [14].

Кірковий індекс, що визначає товщину кори головного мозку у різних ділянках, був запропонований як потенційно важливий діагностичний показник при порушеннях пам' яті. Він може використовуватися для виявлення тонких змін в атрофії головного мозку як скринінговий тест деменції до розвитку дифузної або лобної атрофії [15]. Встановлено, що виконання конструктивних тестів на зорово-просторову функцію корелює з товщиною кори тім' яних часток, тоді як здатність виконувати зорово-специфічні тести найкраще відповідає товщині кори скроневої частки [16]. Доведено, що при ранніх стадіях хвороби Альцгеймера одночасне визначення показників об'єму скроневої частки, товщини кори та уповільнення ЕЕГ-активності найточніше корелюють із показниками когнітивного статусу [17].

Прогресивне розширення шлуночкової системи під час старіння є загальною знахідкою в паренхімі мозку в осіб похилого віку. Шлуночкова система також поступово збільшується при деяких нейродегенеративних захворюваннях, таких як хвороба Альцгеймера, хвороба Паркінсона і прогресуючий над' ядерний параліч. Хронічна гідроцефалія (ГЦ) - це складний стан, що характеризується вентрикуломегалією, з надмірним накопиченням спинномозкової рідини, за відсутності значного підвищення або хронічного зниження внутрішньочерепного тиску [18]. При ідіопатичній хронічній ГЦ встановлено прогресування когнітивних порушень паралельно зі збільшенням розмірів шлуночків в тім' яно-потиличних та скроневих відділах [19].

Проте, незважаючи на високу зацікавленість вчених когнітивною сферою людини, чітких морфометричних маркерів [20] ранніх когнітивних порушень та предикторів наступного зростання когнітивної неспроможності не існує $[21,22]$.

Мета - оцінити стан головного мозку за допомогою оцінки морфометричних показників у хворих на XIM з наявністю ГЦ та дослідити їх взаємозв'язок із когнітивною сферою.

Матеріал і методи дослідження. Нами було обстежено 170 хворих на хронічну ішемію мозку віком від 44 до 82 років, які отримували стаціонарне лікування в третьому, другому неврологіч-

них відділеннях та у відділенні когнітивних розладів Тернопільської обласної комунальної клінічної психоневрологічної лікарні. Жінок серед пацієнтів було 73 (42,94\%), чоловіків - 97 (57,06 \%). Середній вік хворих склав $(65,78 \pm 9,11)$ роки.

Фоновим захворюванням у всіх хворих була гіпертонічна хвороба, яка поєднувалася з церебральним атеросклерозом у 92 (65,71 \%) пацієнтів, з ішемічною хворобою серця - у 31 (22,14 \%) хворого, зі стенокардією напруги - у 5 осі6 (3,57 \%), з цукровим діабетом - у 15 (10,71 \%) осіб, з фібриляцією передсердь - у 5 (3,57 \%) обстежуваних.

Гостре порушення мозкового кровообігу в анамнезі спостерігали у 44 (25,88 \%) хворих, в тому числі транзиторні ішемічні атаки -у 24 (14,12 \%) пацієнтів, лакунарний ішемічний інсульт - у 43 $(25,29 \%)$ осіб. Інфаркт міокарда в анамнезі був у $8(4,71 \%)$ пацієнтів.

XIM I ст. діагностовано у 35 (20,59 \%) обстежуваних, XIM II ст. - у 95 (55,88 \%) пацієнтів, XIM III ст. - у 40 (23,53\%) осіб.

Обстежені хворі належали у трьох вікових категорій: 24 (17,14 \%) хворих - у віці від 45 до 59 років, 88 (62,86 \%) хворих - від 60 до 74 років, 28 (20,00 \%) хворих старші 74 років.

Стан когнітивних функцій оцінювали за Монреальською шкалою когнітивних функцій (МоСАтест). Шкала МоСА, порівняно з іншими нейропсихологічними тестами, $\epsilon$ більш чутливою для швидкої діагностики когнітивної дисфункції та дає можливість характеризувати такі параметри когнітивної сфери як зорово-конструктивні навички, увага та концентрація, пам'ять, мова, абстрактне мислення, рахунок, орієнтація.

Морфометрію мозку виконували за даними KT (апарат Asteion Super-4, Toshiba (Японія)) та MPT (Siemens Magnetom Avanto 1,5T), визначали такі показники - ширина субарахноїдальних просторів на рівні полюса лобних часток та сільвієвої борозни; для оцінки шлуночкової системи вимірювали такі характеристики: В - максимальна відстань між бічними шлуночками, С - максимальна відстань між передніми рогами по латеральному краю; D мінімальний розмір бічних шлуночків; E - максимальний розмір 3-го шлуночка; F - максимальна відстань між задніми рогами бічних шлуночків, Ас - внутрішній розмір черепа на рівні краю передніх рогів бічного шлуночка; Ad - внутрішній розмір черепа на рівні хвостатого ядра; Аа - максимальний внутрішній розмір черепа; А - максимальний зовнішній розмір черепа, розмір IV шлуночка, біфронтальний індекс (БФІ), бікаудатний індекс (БКІ), індекс центральної частини бокового шлуночка (ІЦЧБШ), шлуночковий індекс (Ш), індекс фронтальних рогів (IФР), індекс Хакмана (IX), індекс Шлатенбрандта - Нюрнберга (IШH), співвід- 
Огляди літератури, оригінальні дослідження, погляд на проблему, випадок з практики, короткі повідомлення ношення Еванса (СЕ). Факт зовнішньої церебральної атрофії підтверджували вимірюванням розмірів САП. 3 метою діагностики внутрішньої церебральної атрофії використовували розміри 3-го шлуночка, ширина якого в нормі не повинна перевищувати 0,68 см. При розширенні в межах 0,7-0,75 см діагностували легку внутрішню ЦА; 0,76-0,8 см - помірну; 0,8 см та більше - виражену ЦА.

Статистичний аналіз проводили на персональному комп'ютері з використанням програми Statistica v. 6.1.

Результати й обговорення. Усіх хворих було поділено на дві групи. 1-у групу склали 140 хворих $(82,35 \%)$ з XIM, у яких були ознаки внутріш-

ньої, зовнішньої чи змішаної ГЦ, серед них було 88 чоловіків (62,86 \%) та 52 жінки (37,14 \%) віком від 49 до 82 років, середній вік яких склав $(64,89 \pm 8,74)$ років. Середній бал за шкалою МОСА склав $(15,65 \pm 4,11)$ балів.

До 2-ї групи (групи порівняння) увійшли 30 пацієнтів $(21,43 \%)$ з ХІМ без проявів ГЦ, серед них були 21 жінка (70\%) та 9 чоловіків (30\%) віком від 44 до 76 років, середній вік яких склав $(63,56 \pm$ $9,49)$ років. Також було обстежено 20 здорових людей, репрезентативних за віком та статтю, які склали контрольну групу. Середній бал за шкалою МОСА склав $(20,64 \pm 2,59)$ балів.

Результати морфометрії головного мозку за даними МСКТ наведено в таблиці 1.

Таблиця 1. Морфометричні характеристики головного мозку хворих з хронічною ішемією мозку за даними комп' ютерної томографії $(\mathrm{M} \pm \mathrm{m})$

\begin{tabular}{|c|c|c|c|}
\hline Показник & Контрольна група, n=20 & 1 група, n=140 & 2 група, n=30 \\
\hline Передній ріг правого БШ, см & $0,58 \pm 0,02$ & $1,23 \pm 0,02^{*}$ & $0,59 \pm 0,02$ \\
\hline Передній ріг лівого БШ, см & $0,59 \pm 0,02$ & $1,29 \pm 0,02 * *$ & $0,60 \pm 0,02$ \\
\hline Правий БШ, см & $0,56 \pm 0,02$ & $1,29 \pm 0,03 * *$ & $0,59 \pm 0,02$ \\
\hline Лівий БШ, см & $0,57 \pm 0,02$ & $1,32 \pm 0,03^{*}$ & $0,60 \pm 0,02$ \\
\hline 3 шлуночок, см & $0,44 \pm 0,01$ & $0,9 \pm 0,02^{*}$ & $0,59 \pm 0,02$ \\
\hline ІЦЧБШ & $10,58 \pm 0,44$ & $6,78 \pm 0,24 * *$ & $9,98 \pm 0,44$ \\
\hline 4 шлуночок, см & $0,91 \pm 0,02$ & $1,41 \pm 0,02$ & $0,96 \pm 0,02$ \\
\hline БФІ & $0,29 \pm 0,01$ & $0,45 \pm 0,00 *$ & $0,34 \pm 0,01$ \\
\hline БKI & $0,12 \pm 0,02$ & $0,26 \pm 0,00 *$ & $0,14 \pm 0,02$ \\
\hline 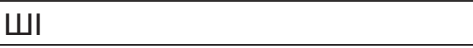 & $0,39 \pm 0,01$ & $0,53 \pm 0,00 * *$ & $0,41 \pm 0,01$ \\
\hline IФP & $0,47 \pm 0,01$ & $0,69 \pm 0,00 *$ & $0,50 \pm 0,01$ \\
\hline Індекс Хакмана & $2,21 \pm 0,08$ & $1,98 \pm 0,04^{*}$ & $2,35 \pm 0,08$ \\
\hline $\begin{array}{l}\text { Індекс Шлатенбрандта - } \\
\text { Нюрнберга }\end{array}$ & $36,27 \pm 1,95$ & $16,31 \pm 0,93 *$ & $30,27 \pm 1,95$ \\
\hline САП (полюс лобної частки), см & $0,29 \pm 0,02$ & $0,72 \pm 0,01^{*}$ & $0,30 \pm 0,02$ \\
\hline САП (Сільвієва борозна), см & $0,32 \pm 0,02$ & $0,88 \pm 0,02 *$ & $0,44 \pm 0,02$ \\
\hline Співвідношення Еванса & $0,28 \pm 0,01$ & $0,4 \pm 0,00 *$ & $0,30 \pm 0,01$ \\
\hline
\end{tabular}

Примітка. * - показники достовірні по відношенню до значень групи 2 ( $<<0,01)$; ** - показники достовірні по відношенню до значень групи $2(p<0,05)$.

Ми виявили, що у пацієнтів групи 1, незалежно від локалізації, форми та ступеня вираження ГЦ, достовірно різнилися всі наступні показники, окрім розміру 4-го шлуночка, який також був більшим у пацієнтів групи 1 та склав $(1,41 \pm 0,02)$ проти $(0,96 \pm 0,02)$. Втім, це був єдиний показник, який не виявився достовірним $(p>0,05)$. Аналізуючи отримані результати ми достовірно зафіксували ознаки як кіркового так і підкіркового атрофічного процесу у пацієнтів групи 1.

Ми спробували виявити взаємозв'язок між морфометричними показниками та станом когнітивної сфери і для цього провели визначення кореляційних зв'язків. Було отримано такі результати: встановлено помірний зворотний кореляційний зв'язок ( $r=-0,39, p=0,010)$ між значенням шкали МоСА та розміром лівого бокового шлуночка та слабкий ( $r=-0,29, p=0,046)$ - правого бокового шлуночка; а також помірний зворотний кореляційний зв'язок між значенням шкали МоСА та розміром ПР правого БШ (r=-0,39, $p=0,009)$ і лівого БШ $(r=-0,37$, $\mathrm{p}=0,02)$. Також виявлені кореляції: МoCA/IX ( $r=-0,32$, $p=0,016)$, МоCА/ІЦЧБШ $(r=-0,31, p=0,043)$, МоCA/ БФI( $r=-0,36, p=0,011)$, МоСА/індексомШлатенбрандта-Нюрнберга $(r=-0,44, p=0,012)$, MoCA/IФP $(r=-0,32$, $p=0,002)$, МоСА $/ 3$ шлуночок $(r=-0,35, p=0,012)$; МоСА/САП (полюс лобної частки) ( $r=-0,30, p=0,012)$.

Для виявлення особливостей ГЦ ми поділили всіх пацієнтів групи 1 залежно від форми ГЦ (рис. 1, табл. 2). 
Огляди літератури, оригінальні дослідження, погляд на проблему, випадок з практики, короткі повідомлення

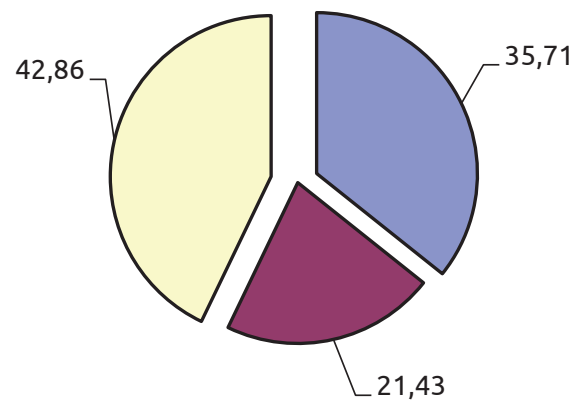

口Внутрішня

口Зовнішня

口змішана

Рис. 1. Форми гідроцефалії у пацієнтів з хронічною ішемією мозку, \%.

Таблиця 2. Морфометричні характеристики головного мозку хворих з хронічною ішемією мозку

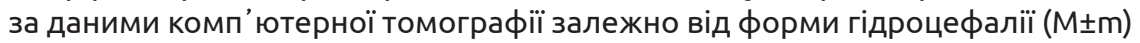

\begin{tabular}{|c|c|c|c|}
\hline Показник & 1А група, n=50 & 1Б група, n=30 & 1В група, n=60 \\
\hline Передній ріг правого БШ, см & $\begin{array}{c}1,66 \pm 0,0 \\
p A-5<0,01 \\
p A-B<0,01\end{array}$ & $\begin{array}{l}0,73 \pm 0,02 \\
\mathrm{p} 5-\mathrm{B}<0,05\end{array}$ & $1,30 \pm 0,04$ \\
\hline Передній ріг лівого БШ, см & $\begin{array}{l}1,78 \pm 0,01 \\
p A-5<0,01 \\
p A-B<0,01\end{array}$ & $\begin{array}{l}0,75 \pm 0,05 \\
\mathrm{p} 5-\mathrm{B}<0,05\end{array}$ & $1,34 \pm 0,04$ \\
\hline Правий БШ, см & $\begin{array}{l}1,79 \pm 0,02 \\
\text { pA- } 5<0,01 \\
\text { pA-B }<0,05\end{array}$ & $\begin{array}{l}0,69 \pm 0,02 \\
\mathrm{p} 5-\mathrm{B}<0,01\end{array}$ & $1,39 \pm 0,02$ \\
\hline Лівий БШ, см & $\begin{array}{l}1,85 \pm 0,02 \\
\mathrm{pA}-\mathrm{-}<0,01\end{array}$ & $\begin{array}{l}0,71 \pm 0,04 \\
\mathrm{p} 5-\mathrm{B}<0,01\end{array}$ & $1,40 \pm 0,02$ \\
\hline 3 шлуночок, см & $\begin{array}{l}1,13 \pm 0,02 \\
p A-5<0,01\end{array}$ & $\begin{array}{l}0,59 \pm 0,02 \\
\mathrm{p} 5-\mathrm{B}<0,01\end{array}$ & $0,98 \pm 0,06$ \\
\hline ІЦЧБШ & $\begin{array}{l}5,15 \pm 0,26 \\
\text { pA- }-<0,01 \\
\text { pA-B }<0,01\end{array}$ & $\begin{array}{l}9,43 \pm 0,22 \\
\mathrm{p} 5-\mathrm{B}<0,01\end{array}$ & $6,76 \pm 0,24$ \\
\hline 4 шлуночок, см & $2,03 \pm 0,02$ & $0,98 \pm 0,02$ & $1,22 \pm 0,02$ \\
\hline БФ। & $\begin{array}{l}0,58 \pm 0,00 \\
p A-5<0,01 \\
\text { pA-B<0,01 }\end{array}$ & $\begin{array}{l}0,35 \pm 0,01 \\
\mathrm{p} 5-\mathrm{B}<0,01\end{array}$ & $0,42 \pm 0,00$ \\
\hline БKI & $\begin{array}{l}0,29 \pm 0,00 \\
p A-5<0,01\end{array}$ & $\begin{array}{l}0,22 \pm 0,00 \\
\mathrm{p} 5-\mathrm{B}<0,01\end{array}$ & $0,27 \pm 0,01$ \\
\hline 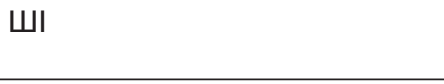 & $\begin{array}{l}0,55 \pm 0,02 \\
p A-5<0,01\end{array}$ & $\begin{array}{l}0,49 \pm 0,02 \\
\mathrm{p} 5-\mathrm{B}<0,01\end{array}$ & $0,56 \pm 0,02$ \\
\hline ІФP & $\begin{array}{l}0,82 \pm 0,01 \\
\text { pA-Б<0,01 } \\
\text { pA-B<0,05 }\end{array}$ & $\begin{array}{l}0,54 \pm 0,00 \\
p 5-B<0,01\end{array}$ & $0,71 \pm 0,00$ \\
\hline Індекс Хакмана & $\begin{array}{l}1,81 \pm 0,02 \\
\text { pA- } 5<0,01 \\
\text { pA-B<0,01 }\end{array}$ & $2,1 \pm 0,05$ & $2,03 \pm 0,05$ \\
\hline $\begin{array}{l}\text { Індекс Шлатенбрандта - } \\
\text { Нюрнберга }\end{array}$ & $\begin{array}{l}6,53 \pm 0,84 \\
\text { pA- } 5<0,01 \\
\text { pA-B<0,01 }\end{array}$ & $\begin{array}{l}24,02 \pm 1,07 \\
p Б-B<0,01\end{array}$ & $18,43 \pm 0,88$ \\
\hline $\begin{array}{l}\text { САП (полюс лобної } \\
\text { частки), см }\end{array}$ & $\begin{array}{l}0,54 \pm 0,02 \\
p A-5<0,05\end{array}$ & $\begin{array}{l}0,87 \pm 0,01 \\
\mathrm{p} 5-\mathrm{B}<0,01\end{array}$ & $0,75 \pm 0,01$ \\
\hline САП (Сільвієва борозна), см & $\begin{array}{l}0,63 \pm 0,02 \\
p A-5<0,05\end{array}$ & $\begin{array}{l}1,04 \pm 0,02 \\
\mathrm{p} 5-\mathrm{B}<0,05\end{array}$ & $0,97 \pm 0,01$ \\
\hline Співвідношення Еванса & $\begin{array}{l}0,47 \pm 0,00 \\
p A-5<0,01\end{array}$ & $\begin{array}{l}0,30 \pm 0,01 \\
\mathrm{p} 5-\mathrm{B}<0,01\end{array}$ & $0,43 \pm 0,00$ \\
\hline
\end{tabular}

Примітка. p<0,01, p<0,05 - достовірна різниця між групами. 
Огляди літератури, оригінальні дослідження, погляд на проблему, випадок з практики, короткі повідомлення

Було діагностовано достовірне розширення всієї шлуночкової системи у 110 пацієнтів групи 1, що підтверджує наявність у них ознак внутрішньої ГЦ (група 1А), причому у 60 хворих (42,86 \%) були наявні ознаки як внутрішньої, так і зовнішньої ГЦ, вони склали групу зі змішаною ГЦ (група 1В). Ознаки зовнішньої ГЦ ми діагностували шляхом вимірювання субарахноїдальних просторів і зафіксували у 90 пацієнтів (64,29\%); з них ізольована зовнішня ГЦ виявлена у 30 хворих (21,43 \%) (група 1Б). Розміри субарахноїдальних просторів на рівні полюса лобної частки у пацієнтів групи 1 були у 2,1 раза, а на рівні Сільвієвої борозни - у 2,2 раза більші, ніж у пацієнтів групи 2.

Отже, ізольована внутрішня ГЦ зафіксована у 50 хворих (35,71\%), змішана форма ГЦ - у 60 хворих (42,86 \%). За оцінкою розмірів III шлуночка у групі 1 ми встановили легку ГЦ у 16 пацієнтів $(11,43 \%)$, помірну - у 55 пацієнтів $(39,29 \%)$ та виражену внутрішню ГЦ-у 39 (27,86 \%) пацієнтів.

3 метою виявлення особливостей кожної з форм ГЦ ми порівняли отримані результати морфометрії у всіх пацієнтів групи 1 (табл. 2).

Аналізуючи отримані результати в залежності від переважної локалізації ГЦ ми достовірно виявили найгірші показники морфометрії у пацієнтів 1А підгрупи, за винятком розмірів борозен. Закономірно, що у пацієнтів 1Б групи були достовірно більші розміри субарахноїдальних просторів, ніж у пацієнтів групи 2. У пацієнтів 1В групи були достовірно гірші всі морфометричні індекси, порівняно з пацієнтами групи 2. Також найгірші показники підкіркової атрофії ми зафіксували у групі 1А, кіркової-у групі 1Б, причому достовірна різниця показників у пацієнтів 15 групи була виявлена між усіма морфометричними значеннями пацієнтів з груп 1A та 1B, за винятком розміру 4 шлуночка. Була виявлена достовірна різниця між морфометричними значеннями у пацієнтів 1A групи та 1B групи за такими показниками: ПР правого та лівого БШ, правий БШ, ІЦЧБШ, БФІ, індекс Шлатенбрандта - Нюрнберга; не було виявлено достовірної різниці між показником лівого БШ, 3 шлуночком, БКІ, Шا, індексом Хакмана, співвідношенням Еванса.

3 метою дослідження стану когнітивних функцій залежно від локалізації ГЦ ми вирішили дослідити залежність результатів шкали МоСА та морфометричних показників головного мозку за допомогою визначення кореляційних зв'язків між ними.
У пацієнтів із внутрішньою ГЦ при XIM (група 1А) були виявлені такі кореляційні зв'язки: помірний зворотний - між зорово-конструктивними навичками та ІФР ( $r=-0,42, p=0,003)$, помірний зворотний - між балами за підшкалою мовлення та БKI $(r=-0,64, p=0,009)$, помірний зворотний - між балами за орієнтацію та БKІ $(r=-0,48, p=0,008)$, МоСА/ширина лівого БШ ( $r=-0,51, p=0,022)$, МоСА/ БKI $(r=-0,46, \quad p=0,018), \quad$ МоСА/ІЦЧБШ $(r=0,64$, $p=0,021$ ).

У пацієнтів із зовнішньою ГЦ (група 1Б) був виявлений помірний зворотний кореляційний зв'язок між рівнем пам'яті та БФІ $(r=-0,52, p=0,019)$, MоСА/БФІ ( $r=-0,50, p=0,001)$, MoCA/БKI $(r=-0,65$, $p=0,001)$, МоCА/ІЦЧБШ $(r=0,66, p=0,002)$, MoCA/ ІПР $(r=0,75, p=0,003)$, МоСА/ширина лівого БШ $(r=-0,64, p=0,018)$.

У пацієнтів зі змішаною гідроцефалією при XIM (група 1В) був виявлений кореляційний зв'язок між балами за орієнтацію та БKI ( $\ulcorner=-0,55$, $\mathrm{p}=0,011)$, а також між балами за абстракцію та БФІ $(r=-0,47, p=0,015)$, балами за абстракцію та БKI ( $r=-$ $0,55, p=0,012)$. МоСА/ЦЧБШ $(r=0,50, p=0,012)$, МоСА/ІПР ( $r=0,50, p=0,006)$, МоСА/лівий боковий шлуночок ( $r=-0,51, p=0,025)$, МоСА/ширина третього шлуночка ( $r=-0,58, p=0,008)$, МоСА/ширина субарахноїдальних просторів на рівні полюса лобних часток ( $r=-0,63, p=0,004)$, МоСА/індекс Шлатенбрандта - Нюрнберга $(r=0,45, p=0,048)$.

Висновки. 1. Залежно від переважної локалізації ГЦ у пацієнтів із хронічною ішемією мозку, змішану ГЦ було виявлено у 42,86 \% хворих, внутрішню - у 35,71 \% хворих, зовнішню - у 21,43 \% хворих.

2. Виявлена залежність між морфометричними показниками, які свідчать про підкіркову та кіркову церебральну атрофію, та вираженням когнітивного дефіциту.

3. Дослідження морфометричних змін головного мозку дозволяє оптимізувати діагностичну тактику та сприяє прогнозуванню когнітивного дефіциту у пацієнтів з хронічною ішемією мозку.

Перспективи подальших досліджень. У перспективі доцільно дослідити морфометричні зміни головного мозку у пацієнтів з XIM залежно від ступеня вираження ГЦ, віку та статі пацієнтів. Вивчення структурних змін головного мозку у пацієнтів з XIM, з'ясування їх зв' язку з когнітивними розладами сприятиме удосконаленню діагностичних підходів та оптимізації прогнозування перебігу захворювання. 


\section{ЛІТЕРАТУРА}

1. Старение и нейродегенеративные расстройства: когнитивные и двигательные нарушения в пожилом возрасте / Д. В. Артемьев, В. В. Захаров, О. С. Левин [и др.] ; под ред. Н. Н. Яхно. - М. : Servier, 2005. - 48 с.

2. Хронічна ішемія мозку (дисциркуляторна енцефалопатія): механізми розвитку та деякі напрями сучасного комплексного лікування / Т. Батишева, І. Артемова, Т. Вдовиченко [та ін.] // Ліки України. - 2004. № 11. - С. 79-83.

3. Шестопалова Л. Ф. Особливості когнітивних порушень у хворих на дисциркуляторну енцефалопатію різних стадій з фібриляцією передсердь / Л. Ф. Шестопалова, Т. С. Міщенко, В. Г. Деревецкая // Укр. вісник психоневрології. - 2005. - Т. 13, вип. 2 (42). - С. 78-81.

4. American Psychiatric Association. Diagnostic and Statistical Manual of Mental Disorders. 4th ed. - Washington DC, 1994. - 873 p.

5. Бомко М. О. Морфометрична нейровізуалізаційна характеристика органічного ураження головного мозку у віддалений період впливу іонізуючого випромінювання внаслідок Чорнобильської катастрофи / М. О. Бомко // Український медичний часопис. - 2004. № 2 (40).

6. Relevance of magnetic resonance imaging for early detection and diagnosis of Alzheimer disease / S. J. Teipel, M. Grothe, S. Lista [et al.] // Med. Clin. North. Am. - 2013. Vol. 97 (3). - P. 399-424.

7. Hippocampal morphometry in population-based incident Alzheimer's disease and vasculardementia: the HAAS / A. I. Scher, Y. Xu, E. S. Korf [et al.] // J. Neurol. Neurosurg. Psychiatry. - 2011. - Vol. 82 (4). - P. 373-376.

8. Cerebral gray matter volume reduction in subcortical vascular mild cognitive impairment patients and subcortical vascular dementia patients, and its relation with cognitive deficits / M. Li, Y. Meng, M. Wang [et al.] // J. Alzheimers Dis. - 2017. - Vol. 58 (3). - P. 927-937.

9. Beyond a differential diagnosis: cognitive and morphometric decoding of information processing speed in senior adults with DSM-5 mild neurocognitive disorders / H. Lu, S. S. M. Chan, A. W. T. Fung, L. C. W. Lam // J. Alzheimers Dis. - 2017. - Vol. 58 (3). - P. 927-937. DOI: 10.3233/JAD-161122.

10. Normal human aging factors contributing to cerebral atrophy / H. Akyama, J. S. Meyer, K. F. Mortel [et al.] // J. Neurol. Sci. - 1997. - Vol. 152. - P. 39-49.

11. Vieira R. T. Subcortical atrophy in frontotemporal dementia and Alzheimer's disease: Significance for the differential diagnosis and correlations with clinical mani- festations / R. T. Vieira, L. Caixeta // Dement. Neuropsychol. - 2008. - Vol. 2 (4). - P. 284-288.

12. Магонов Е. П. Комплексная магнитно-резонансная морфометрия очаговых и атрофических изменений головного мозга (на примере рассеянного склероза и ранних стадий ВИЧ-инфекции) : автореф. дисс. на соискание уч. степени канд. мед. наук. Спец. 14.01.13 - лучевая диагностика, лучевая терапия / Е. П. Магонов. - СПб., 2015.

13. Woods B. T. Is the VBR still a useful measure of changes in the cerebral ventriclesk / B. T. Woods, A. Douglass, B. Gescuk // Psychiatry Res. - 1991. - Vol. 40 (1). - P. 1-10.

14. Comparative study of subcortical atrophy in patients with frontotemporal dementia and dementia with extrapyramidal signs / L. Caixeta, R. T. Vieira, F. Paes [et al.] // Clin. Pract. Epidemiol. Ment. Health. -2015. - Vol. 11. P. 125-129.

15. Cortical thickness in frontotemporal dementia, mild cognitive impairment, and Alzheimer's disease / P. Hartikainen, J. Räsänen, V. Julkunen [et al.] // J. Alzheimers Dis. - 2012. - Vol. 30 (4). - P. 857-874.

16. The relationship between neuropsychological tests of visuospatial function and lobar cortical thickness / D. N. Zink, J. B. Miller, J. Z. K. Caldwell [et al.] // J. Clin. Exp. Neuropsychol. - 2018. - Vol. 40 (5). - P. 518-527.

17. Neuroimaging markers of global cognition in early Alzheimer's disease: A magnetic resonance imaging-electroencephalography study / M. Waser, T. Benke, P. Dal-Bianco [et al.] // Brain Behav. - 2019. - Vol. 9 (1). - P. e01197.

18. Beer de M. H. Cognitive decline in patients with chronic hydrocephalus and normal aging: growing into deficits / M. H. de Beer, P. Scheltens // Dement. Geriatr. Cogn. Dis. Extra. - 2016. - Vol. 6 (3). - P. 500-507.

19. Missori P. Progressive cognitive impairment evolving to dementia parallels parieto-occipital and temporal enlargement in idiopathic chronic hydrocephalus: a retrospective cohort study / P. Missori, A. Currà // Front. Neurol. - 2015. - Vol. 6. - P. 15.

20. Жулкевич І. В. Клініко-діагностична апробація методу віртуальної біопсії кісткової тканини у хворих на лімфому Годжкіна / І. В. Жулкевич, Ю.В.Яворська // Український радіологічний журнал. - 2015. - Т. XXIII. C. 31-34.

21. Деменции / Н. Н. Яхно, В. В. Захаров, А. Б. Локшина [и др.]. - М. : МЕДпресс-информ, 2011. - 272 с.

22. Narayanan L. What can imaging tell us about cognitive impairment and dementia? / L. Narayanan, A. D. Murray // World J. Radiol. - 2016. - Vol. 8 (3). - P. 240-254.

\section{REFERENCES}

1. Artemyev, D.V., Zakharov, V.V., Levin, O.S. Preobrazhenskaya, I.S., \& Yakhno, N.N. (2005). Stareniye i neyrodegenerativnyye rasstroystva: kognitivnyye i dvigatelnyye narusheniya $v$ pozhilom vozraste [Aging and neurodegenerative disorders: cognitive and movement impairments in old age]. Yakhno, N.N. (Ed.). Moscow: Servier [in Russian].

2. Batysheva, T., Artemova, I., Vdovychenko, T., Volovets, S., Hanzhula, P., Haponova, O. ..., \& Boyko, A. (2004).
Khronichna ishemiia mozku (dystsyrkuliatorna entsefalopatiia): mekhanizmy rozvytku ta deiaki napriamy suchasnoho kompleksnoho likuvannia [Chronic cerebral ischemia (dyscirculatory encephalopathy): mechanisms of development and some areas of modern complex treatment]. Liky Ukrainy - Medicines of Ukraine, 11, 79-83 [in Ukrainian].

3. Shestopalova, L.F., Mishchenko, T.S., \& Derevetskaya, V.H. (2005). Osoblyvosti kohnityvnykh porushen u 
Огляди літератури, оригінальні дослідження, погляд на khvorykh na dystsyrkuliatornu entsefalopatiiu riznykh stadii z fibryliatsiieiu peredserd [Peculiarities of cognitive disorders in patients with dyscirculatory encephalopathy of different stages with atrial fibrillation]. Ukr. visnyk psykhonevrolohii - Ukr. Bulletin of Psychoneurology, 13, 2 (42), 78-81 [in Ukrainian].

4. American Psychiatric Association (1994). Diagnostic and Statistical Manual of Mental Disorders. 4th Ed. Washington DC.

5. Bomko, M.O. (2004). Morfometrychna neirovizualizatsiina kharakterystyka orhanichnoho urazhennia holovnoho mozku u viddalenyi period vplyvu ionizuiuchoho vyprominiuvannia vnaslidok Chornobylskoi katastrofy [Morphometric neuroimaging characteristics of organic brain damage in the long term exposure to ionizing radiation due to the Chernobyl disaster]. Ukrainskyi medychnyi chasopys Ukrainian Medical Journal, 2 (40) [in Ukrainian].

6. Teipel, S.J., Grothe, M., Lista, S., Toschi, N., Garaci, F.G., \& Hampel, H. (2013). Relevance of magnetic resonance imaging for early detection and diagnosis of Alzheimer disease. Med. Clin. North. Am., 97 (3), 399-424.

7. Scher, A.I., Xu, Y., Korf, E.S., Hartley, S.W., Witter, M.P., Scheltens, P., ..., \& Launer, LJ. (2011). Hippocampal morphometry in population-based incident Alzheimer's disease and vasculardementia: the HAAS. J. Neurol. Neurosurg. Psychiatry, 82 (4), 373-376.

8. Li, M., Meng, Y., Wang, M., Yang, S., Wu, H., Zhao, B., \& Wang, G. (2017). Cerebral gray matter volume reduction in subcortical vascular mild cognitive impairment patients and subcortical vascular dementia patients, and its relation with cognitive deficits. J. Alzheimers Dis., 58 (3), 927-937.

9. Lu, H., Chan, S.S.M., Fung, A.W.T., \& Lam, L.C.W. (2017). Beyond a differential diagnosis: cognitive and morphometric decoding of information processing speed in senior adults with DSM-5 mild neurocognitive disorders. J. Alzheimers Dis., 58 (3), 927-937. DOI: 10.3233/ JAD-161122.

10. Akiyamaa, H., Meyera, J.S., Mortela, K.F., Terayamaa, Y., Thornbyb, J.I., \& Konnoa, S. (1997). Normal human aging factors contributing to cerebral atrophy. J. Neurol. Sci., 152, 39-49.

11. Vieira, R.T., \& Caixeta, L. (2008). Subcortical atrophy in frontotemporal dementia and Alzheimer's disease: Significance for the differential diagnosis and correlations with clinical manifestations. Dement. Neuropsychol., 2 (4), 284-288.

12. Magonov, Ye.P. (2015). Kompleksnaya magnitnorezonansnaya morfometriya ochagovykh i atroficheskikh izmeneniy golovnogo mozga (na primere rasseyannogo роблему, випадок з практики, короткі повідомлення skleroza i rannikh stadiy VICH-infektsii) [Complex magnetic resonance morphometry of focal and atrophic changes in the brain (on the example of multiple sclerosis and early stages of HIV infection)]. Candidate's thesis. Saint-Petersburg [in Russian].

13. Woods, B.T., Douglass, A., \& Gescuk, B. (1991). Is the VBR still a useful measure of changes in the cerebral ventriclesk. Psychiatry Res., 40 (1), 1-10.

14. Caixeta, L., Vieira, R.T., Paes, F., Carta, M.G., Nardi, A.E., Arias-Carrión, O., ..., \& Machado, S. (2015). Comparative study of subcortical atrophy in patients with frontotemporal dementia and dementia with extrapyramidal signs. Clin. Pract. Epidemiol. Ment. Health., 11, 125-129.

15. Hartikainen, P., Räsänen, J., Julkunen, V., Niskanen, E., Hallikainen, M., Kivipelto, M., ..., \& Soininen, $H$. (2012). Cortical thickness in frontotemporal dementia, mild cognitive impairment, and Alzheimer's disease. J. Alzheimers Dis., 30 (4), 857-74.

16. Zink, D.N., Miller, J.B., Caldwell, J.Z.K., Bird, C., \& Banks, S.J. (2018). The relationship between neuropsychological tests of visuospatial function and lobar cortical thickness. J. Clin. Exp. Neuropsychol., 40 (5), 518-527.

17. Waser, M., Benke, T., Dal-Bianco, P., Garn, H., Mosbacher, J.A., Ransmayr, G., ..., \& Jennum, P.J. (2019). Neuroimaging markers of global cognition in early Alzheimer's disease: A magnetic resonance imaging-electroencephalography study. Brain Behav., 9 (1), e01197.

18. Beer, de M.H., \& Scheltens, P. (2016). Cognitive decline in patients with chronic hydrocephalus and normal aging: growing into deficits. Dement. Geriatr. Cogn. Dis. Extra., 6 (3), 500-507.

19. Missori, P., \& Currà, A. (2015). Progressive cognitive impairment evolving to dementia parallels parietooccipital and temporal enlargement in idiopathic chronic hydrocephalus: a retrospective cohort study. Front. Neurol., 6, 15.

20. Zhulkevych, I.V., \& Yavorska, Yu.V. (2015). Klinikodiahnostychna aprobatsiia metodu virtualnoi biopsii kistkovoi tkanyny u khvorykh na limfomu Hodzhkina [Clinical and diagnostic testing of the method of virtual biopsy of bone tissue in patients with Hodgkin's lymphoma]. Ukrayinskyi radiolohichnyi zhurnal - Ukrainian Journal of Radiology, XXIII, 31-34 [in Ukrainian].

21. Yakhno, N.N., Zakharov, V.V., Lokshina, A.B., Koberskaya, N.N., \& Mkhitaryan, E.A. (2011). Dementsii [Dementia]. Moscow: MEDpress-inform [in Russian].

22. Narayanan, L., \& Murray, A.D. (2016). What can imaging tell us about cognitive impairment and dementia? World J. Radiol., 8 (3), 240-254.

\title{
МОРФОМЕТРИЧЕСКАЯ ХАРАКТЕРИСТИКА ГОЛОВНОГО МОЗГА У БОЛЬНЫХ ХРОНИЧЕСКОЙ ИШЕМИЕЙ МОЗГА
}

๑Р. Б. Насалык

\author{
Тернопольский национальный медицинский университет имени И. Я. Горбачевского МОз Украины
}

РЕзЮМЕ. Изучение структурных изменений головного мозга у пациентов с хронической ишемией мозга (ХИМ), определение их связи с когнитивными расстройствами способствует усовершенствованию диагностических подходов и оптимизации прогнозирования течения заболевания. 
Огляди літератури, оригінальні дослідження, погляд на проблему, випадок з практики, короткі повідомлення

Цель - оценить состояние головного мозга с помощью определения морфометрических показателей у больных ХИМ с наличием гидроцефалии (ГЦ) и исследовать их взаимосвязь с когнитивной сферой.

Материал и методы. Проведено комплексное обследование 140 пациентов с ХИМ и ГЦ. Учитывали локализацию ГЦ, данные Монреальского когнитивного теста. Оценивали данные компьютерной томографии головного мозга с последующим определением морфометрических показателей и индексов. Для статистической обработки результатов пользовались программами Microsoft Excel 2011, Statistica.

Результаты. По данным морфометрии, у пациентов с хронической ишемией мозга обнаруживали как внутреннюю форму ГЦ (у 50 больных (35,71\%)), так и внешнюю (у 30 больных (21,43\%)) и смешанную ГЦ (у 60 больных $(42,86 \%))$. Средний балл по шкале МОСА у больных ХИМ с ГЦ составил $(15,65 \pm 4,11)$, у больных ХИМ без ГЦ $(20,64 \pm 2,59)$. Установлена умеренная обратная корреляционная связь $(r=-0,39, p=0,010)$ между значением по шкале МоСА и размером левого бокового желудочка, МоСА/ИХ ( $r=-0,32, p=0,016)$, МоСа/ИЦчБЖ ( $r=-0,31, p=0,043)$, МоСа/БФИ ( $r=-0,36, p=0,011)$, МоСА/индексом Шлатенбрандта - Нюрнберга $(r=-0,44, p=0,012)$, МоСА/ИФР ( $r=-0,32$, $\mathrm{p}=0,002), \mathrm{MoСa} / 3$ желудочек ( $r=-0,35, \mathrm{p}=0,012)$ МоСА/САП (полюс лобной доли) $(r=-0,30, p=0,012)$.

В группах пациентов с внутренней и смешанной ГЦ установлены достоверно худшие морфометрические характеристики. Установлена зависимость между морфометрическими показателями, которые свидетельствуют о подкорковой и корковой церебральной атрофии, и выраженностью когнитивного дефицита в зависимости от формы ГЦ.

Выводы. У пациентов с хронической ишемией мозга смешанная ГЦ была обнаружена у 42,86 \%, Внутренняя у 35,71 \%, внешняя - у 21,43 \% обследованных. Выявлена зависимость между морфометрическими показателями, которые свидетельствуют о подкорковой и корковой церебральной атрофии, и выраженностью когнитивного дефицита.

КЛЮЧЕВЫЕ СЛОВА: хроническая ишемия мозга; гидроцефалия; компьютерная томография; церебральная атрофия.

\section{MORPHOMETRIC CHARACTERISTICS OF THE BRAIN IN PATIENTS WITH CHRONIC BRAIN ISCHEMIA}

\section{Horbachevsky Ternopil National Medical University}

@R. B. Nasalyk

SUMMARY. The study of structural changes of the brain in patients with chronic brain ischemia (CBI), elucidation of their relationship with cognitive disorders contributes to the improvement of diagnostic approaches and optimization of predicting the course of the disease. The aim is to assess the state of the brain by determining morphometric parameters in patients with $\mathrm{CBI}$ and hydrocephalus $(\mathrm{HC})$ and to investigate their relationship with the cognitive sphere.

Material and Methods. A comprehensive examination of 140 patients with CBI and HC was carried out. We took into account the localization of HC, the data of the Montreal cognitive test. The data of computed tomography of the brain were evaluated, followed by the determination of morphometric parameters and indices. For statistical processing of the results, we used Microsoft Excel 2011 and Statistica programs.

Results. According to morphometric data, in patients with CBI, both the internal form of HC (in 50 patients ( $35.71 \%$ )) and external (in 30 patients $(21.43 \%)$ ) and mixed HC (in 60 patients (42.86\%)) were found. The average score on the MoCA scale in patients with CBI with HC was $(15.65 \pm 4.11)$ points, in patients with CBI without $\mathrm{HC}-(20.64 \pm 2.59)$ points. A moderate inverse correlation was found $(r=-0.39, p=0.010)$ between the value of the MoCA scale and the size of the left lateral ventricle, MoCA/IH ( $r=-0.32, p=0.016)$, MoCA/ICPLV $(r=-0,31, p=0,043)$, MoCF/BFI $(r=-0.36, p=0.011), M o C A /$ Schlatenbrand-Nuremberg index $(r=-0.44, p=0.012)$, MoCA/IFH $(r=-0.32, p=0.002)$, MoCA/3 ventricle $(r=-0.35, p=0.012)$ MoCA/SAP (frontal lobe pole) ( $r=-0.30, p=0.012)$.

Conclusions. Depending on the predominant localization of HC in patients with CBI, mixed HC was found in $42.86 \%$ of patients, internal - in $35.71 \%$ of patients, external - in $21.43 \%$ of patients. A relationship was found between morphometric indicators, which indicate subcortical and cortical cerebral atrophy, and the severity of cognitive deficit.

KEY WORDS: chronic cerebral ischemia; hydrocephalus; CT scan; cerebral atrophy. 